\title{
Glucagon Potentiates Insulin Secretion Via $\beta$-Cell GCGR at Physiological Concentrations of Glucose
}

\author{
Yulin Zhang ${ }^{1,+}+{ }^{+}$, Chengsheng Han ${ }^{1,+}$, Wenzhen Zhu ${ }^{1}$, Guoyi Yang ${ }^{1}$, Xiaohong Peng ${ }^{1}$, Sohum Mehta ${ }^{2}$, \\ Jin Zhang ${ }^{2}$, Liangyi Chen ${ }^{1,3,4, *}$ and Yanmei Liu ${ }^{5, *(1)}$
}

1 State Key Laboratory of Membrane Biology, Beijing Key Laboratory of Cardiometabolic Molecular Medicine, Institute of Molecular Medicine, College of Future Technology, Peking University, Beijing 100871, China; 1906390239@pku.edu.cn (Y.Z.); hanchengsheng@pku.edu.cn (C.H.); 1201110443@pku.edu.cn (W.Z.); gyyang0611@pku.edu.cn (G.Y.); $2006388450 @$ pku.edu.cn (X.P.)

2 Department of Pharmacology, University of California San Diego, La Jolla, CA 92093-0702, USA; sohum@ucsd.edu (S.M.); jzhang32@ucsd.edu (J.Z.)

3 PKU-IDG/McGovern Institute for Brain Research, Beijing 100871, China

4 Beijing Academy of Artificial Intelligence, Beijing 100871, China

5 Key Laboratory of Brain, Cognition and Education Sciences, Ministry of Education, Institute for Brain

Research and Rehabilitation, South China Normal University, Guangzhou 510631, China

* Correspondence: lychen@pku.edu.cn (L.C.); yanmeiliu@m.scnu.edu.cn (Y.L.)

+ Y.Z. and C.H. contributed equally to this work.

Citation: Zhang, Y.; Han, C.; Zhu, W.; Yang, G.; Peng, X.; Mehta, S.; Zhang,

J.; Chen, L.; Liu, Y. Glucagon

Potentiates Insulin Secretion Via $\beta$-Cell GCGR at Physiological Concentrations of Glucose. Cells 2021, 10, 2495. https://doi.org/10.3390/ cells10092495

Academic Editor: Stephen Yarwood

Received: 1 September 2021

Accepted: 15 September 2021

Published: 21 September 2021

Publisher's Note: MDPI stays neutral with regard to jurisdictional claims in published maps and institutional affiliations.

Copyright: (c) 2021 by the authors. Licensee MDPI, Basel, Switzerland. This article is an open access article distributed under the terms and conditions of the Creative Commons Attribution (CC BY) license (https:// creativecommons.org/licenses/by/ $4.0 /)$.

\begin{abstract}
Incretin-potentiated glucose-stimulated insulin secretion (GSIS) is critical to maintaining euglycemia, of which GLP-1 receptor (GLP-1R) on $\beta$-cells plays an indispensable role. Recently, $\alpha$ cell-derived glucagon but not intestine-derived GLP-1 has been proposed as the critical hormone that potentiates GSIS via GLP-1R. However, the function of glucagon receptors (GCGR) on $\beta$-cells remains elusive. Here, using GCGR or GLP-1R antagonists, in combination with glucagon, to treat single $\beta$-cells, $\alpha$ - $\beta$ cell clusters and isolated islets, we found that glucagon potentiates insulin secretion via $\beta$-cell GCGR at physiological but not high concentrations of glucose. Furthermore, we transfected primary mouse $\beta$-cells with RAB-ICUE (a genetically encoded cAMP fluorescence indicator) to monitor cAMP level after glucose stimulation and GCGR activation. Using specific inhibitors of different adenylyl cyclase (AC) family members, we revealed that high glucose concentration or GCGR activation independently evoked cAMP elevation via AC5 in $\beta$-cells, thus high glucose stimulation bypassed GCGR in promoting insulin secretion. Additionally, we generated $\beta$-cellspecific GCGR knockout mice which glucose intolerance was more severe when fed a high-fat diet (HFD). We further found that $\beta$-cell GCGR activation promoted GSIS more than GLP-1R in HFD, indicating the critical role of GCGR in maintaining glucose homeostasis during nutrient overload.
\end{abstract}

Keywords: glucagon; GCGR; GLP-1R; $\alpha$-cells; $\beta$-cells; glucose-stimulated insulin secretion; cAMP

\section{Introduction}

Insulin released from pancreatic $\beta$-cells, which facilitates glucose uptake and utilization in downstream tissues, such as liver, adipocytes, and muscle, is critical in maintaining tight glucose homeostasis [1]. Orally induced blood glucose elevation triggers two- to threefold more insulin secretion than intravenous glucose injection [2], which is ascribed to the stimulatory effects of intestine-derived incretins, such as glucose-dependent insulinotropic peptide (GIP) and glucagon-like peptide-1 (GLP-1) [3,4]. In humans, GLP-1 is more potent than GIP at stimulating insulin release [5], and its stimulatory effects persist in type 2 diabetes (T2D) patients, while those of GIP diminish [6]. Thus, GLP-1 is widely accepted as an essential incretin for blood glucose homeostasis, and its receptor (GLP-1R) serves as a therapeutic drug target for T2D.

Recently, the critical function of intestine-derived GLP-1 has been challenged. Pancreatic $\beta$-cell-specific GLP-1R knockout mice showed normal oral glucose tolerance but 
impaired intraperitoneal glucose tolerance, indicating an indispensable role of islet-derived rather than intestine-derived ligands in activating GLP-1R in $\beta$-cells during glucose stimulation [7].

GLP-1 is found in pancreatic $\alpha$-cells [8-11], colocalizing with glucagon in the granules of murine $\alpha$-cells [12]. Thus $\alpha$-cell-derived GLP-1 is proposed to potently enhance glucosestimulated insulin secretion (GSIS) $[7,13,14]$. However, the relative concentrations of GLP-1 and glucagon in $\alpha$-cells vary in different studies $[10,11,15]$, and how $\alpha$-cells preferentially release GLP-1 or glucagon from the same granule is also obscure. Glucagon, on the other hand, also stimulates insulin secretion [16] via generating cAMP by binding to both the glucagon receptor (GCGR) and GLP-1R [17-20] on $\beta$-cells. Interestingly, recent studies show that the $\beta$-cell GCGR knockout mice exhibit normoglycaemia [18-20]. Glucagon enhanced GSIS in $10 \mathrm{mM}$ [19] or $12 \mathrm{mM}$ [18] glucose-induced GCGR knockout islets was not different from control islets, suggesting that the major insulinotropic effect of glucagon is achieved via GLP-1R. However, as the cognate downstream receptor of glucagon, the physiological significance of $\beta$-cell GCGR remains unclear, and how it functions under metabolic stress has yet to be established.

This study shows that besides GLP-1R, GCGR also contributes to glucagon-enhanced GSIS at physiological glucose concentrations. However, at high glucose levels, glucagonenhanced GSIS results from GLP-1R only. We found that the possible mechanism may be that high glucose and GCGR activate the same pool of adenylyl cyclase (AC) AC5, increasing cAMP to enhance insulin secretion, while GLP-1R seems to recruit other ACs. By generating and characterizing $\beta$-cell-specific GCGR knockout mice, we confirmed GCGR's effect on insulin secretion at physiological concentrations of glucose. We further found that downstream of glucagon, $\beta$-cell GCGR plays a more prevalent role than GLP-1R in potentiating GSIS in mice fed the high-fat diet (HFD). These data highlight the essential roles of $\beta$-cell GCGR in mediating both glucose homeostasis and metabolic status.

\section{Materials and Methods}

\subsection{Animals}

GluCre-ROSA26EYFP mice were a kindly gifted by Prof. Herbert Y. Gaisano from the University of Toronto (Toronto, Ontario, Canada). For the generation of Gcgrf/f mice, the targeting vector was constructed by inserting an Frt-flanked neomycin cassette in the third intron of Gcgr and two loxP sites in the locations described in Figure 3A, then electroporated into embryonic stem cells from C57BL/6J mice (Beijing Biocytogen Co., Ltd, Beijing, China). The founder mice were mated with an flp-deleter mouse (Jackson Laboratory; stock number 003946) to remove the neomycin cassette. $\beta$-cell-specific GCGR knockout $\left(G \mathrm{cgr}{ }^{\beta c e l l-/-}\right)$ mice were generated by crossbreeding $G c g r f / f$ mice with ins1-cre mice (Jackson Laboratory; stock number 026801) [21]. Upon loxP recombination, exons 4 to 14 of the Gcgr gene were removed in $\beta$ cells. Mice were maintained in one cage with a light/dark cycle of $12 \mathrm{~h}$ and administered a chow diet, ad libitum. Only male mice older than 8 weeks were used in our study and were fed either a normal diet (ND) or HFD with $60 \% \mathrm{kcal}$ fat (D12492, Research Diets) for 3 months before the experiments.

\subsection{IPGTT}

Blood samples were collected via the tail nick for the intraperitoneal glucose tolerance test (IPGTT), and blood glucose was measured with a blood glucose meter (ACCU-CHEK ${ }^{\circledR}$ Active, Roche, Basel, Switzerland). Mice were fasted for $18 \mathrm{~h}$ to achieve relatively low basal glucose levels. Then glucose (G7021, Sigma, Shanghai, China) was administered by intraperitoneal (IP) injection at different doses $(1 \mathrm{~g} / \mathrm{kg}, 2 \mathrm{~g} / \mathrm{kg}$, and $4 \mathrm{~g} / \mathrm{kg})$. Glycaemia was measured at 15, 30, 45, 60, and $120 \mathrm{~min}$ after glucose administration.

\subsection{Isolation of Mouse Islets and Dissociation of the Islets into Individual $\beta$-Cells or Cell Clusters}

Pancreatic islets were isolated from mice as previously described [22]. After overnight culture in RPMI 1640 medium (10\% FBS, C22400500BT, Gibco), islets were washed with 
Hank's balanced salt solution (HBSS) without calcium and magnesium $(5.3 \mathrm{mM} \mathrm{KCl}$, $0.44 \mathrm{mM} \mathrm{KH}_{2} \mathrm{PO}_{4}, 4.16 \mathrm{mM} \mathrm{NaHCO}_{3}, 137.9 \mathrm{mM} \mathrm{NaCl}, 0.34 \mathrm{mM} \mathrm{Na}_{2} \mathrm{HPO}_{4}$ and $5 \mathrm{mM}$ glucose, $\mathrm{pH} 7.4)$ and then treated with $0.25 \%$ trypsin (25200-056, Life Technologies) for $3 \mathrm{~min}$ at $37^{\circ} \mathrm{C}$. The cells were plated on coverslips coated with poly-L-lysine (P4707, Sigma) and cultured in RPMI 1640 medium (10\% FBS, C22400500BT, Gibco) at $37^{\circ} \mathrm{C}$ and $5 \% \mathrm{CO}_{2}$ for $24-48 \mathrm{~h}$ before experiments.

\subsection{Detection of Hormone Secretion from Islets}

After culturing overnight, five similar-sized islets were selected and randomly assigned to each group. After preincubation in KRBB $(125 \mathrm{mM} \mathrm{NaCl}, 5.9 \mathrm{mM} \mathrm{KCl}, 2.56 \mathrm{mM}$ $\mathrm{CaCl}_{2}, 1.2 \mathrm{mM} \mathrm{MgCl}$, $1 \mathrm{mM}$ L-glutamine, $25 \mathrm{mM}$ HEPES, $1 \mathrm{~g} / \mathrm{L} \mathrm{BSA}, 3 \mathrm{mM}$ glucose) for $1 \mathrm{~h}$ at $37^{\circ} \mathrm{C}$, the islets were transferred to another $200 \mu \mathrm{L}$ of KRBB supplemented with the indicated glucose concentrations ( $3 \mathrm{mM}, 5 \mathrm{mM}, 7 \mathrm{mM}, 11 \mathrm{mM}$ and $20 \mathrm{mM}$ ) for $1 \mathrm{~h}$ at $37^{\circ} \mathrm{C}$. Additionally, $1 \mu \mathrm{M}$ MK0893 [23] or $1 \mu \mathrm{M}$ Exendin 9-39 [18,24,25] was included to block GCGR or GLP-1R that was activated by $100 \mathrm{nM}$ glucagon. The incubation solution was then collected, and insulin levels were measured using a rat/mouse insulin ELISA kit according to the manufacturer's instructions (EZRMI-13K, Millipore). Insulin secretion was normalized to ng/islet/h. The key reagent information is as followed (Table 1).

Table 1. The information of glucagon-related drugs.

\begin{tabular}{ccc}
\hline Reagent & Source & Identifier \\
\hline glucagon & Sigma & G2044 \\
MK0893 & Medchem Express & HY-50663 \\
Exendin 9-39 & Sigma & E7269 \\
\hline
\end{tabular}

For glucagon secretion measurements, 25 islets were incubated for $4 \mathrm{~h}$ in $200 \mu \mathrm{L}$ of KRBB containing $7 \mathrm{mM}$ glucose. The glucagon level was measured using a glucagon ELISA kit (10-1271-01, Mercodia, Uppsala, Sweden).

\subsection{Electrophysiology and Membrane Capacitance Recording}

Perforated whole-cell recordings of membrane capacitance $(\mathrm{Cm})$ were used to assess the secretion abilities of single $\beta$-cells $[26,27]$. $\beta$-cells with a $\mathrm{Cm}$ above $4 \mathrm{pF}$ were selected for experiments. The standard extracellular solution contained $118 \mathrm{mM} \mathrm{NaCl}, 20 \mathrm{mM}$ tetraethylammonium chloride (TEA), $5.6 \mathrm{mM} \mathrm{KCl}, 2.6 \mathrm{mM} \mathrm{CaCl}_{2} \cdot 2 \mathrm{H}_{2} \mathrm{O}, 1.2 \mathrm{mM} \mathrm{MgCl}$, 5- or 20-mM D-glucose and $5 \mathrm{mM}$ HEPES at $\mathrm{pH}$ 7.4. The intracellular solution contained $152 \mathrm{mM} \mathrm{CsCH}_{3} \mathrm{SO}_{3}, 10 \mathrm{mM} \mathrm{CsCl}, 10 \mathrm{mM} \mathrm{KCl}, 1 \mathrm{mM} \mathrm{MgCl}_{2}$ and $5 \mathrm{mM}$ HEPES, and the $\mathrm{pH}$ was adjusted to $7.35 \mathrm{using} \mathrm{CsOH}$. Then, $100 \mu \mathrm{g} / \mathrm{mL}$ nystatin was added to the intracellular solution for perforation. Pulses depolarized from -70 to $0 \mathrm{mV}$ by a voltage clamp were used to induce exocytosis. The stimulus train $(\mathrm{Cm} 5+14)$ consisted of five $50 \mathrm{~ms}$ pulses followed by fourteen $500 \mathrm{~ms}$ pulses ( $100 \mathrm{~ms}$ intervals between pulses) to completely deplete the readily releasable pool (RRP) of vesicles.

\subsection{Fluorescence Imaging of cAMP}

Live-cell imaging of cAMP dynamics was performed using RAB-ICUE [28], a genetically encoded fluorescent cAMP indicator, in which amino acids 149-881 of Epac1 are sandwiched between a dimerization-dependent red fluorescent protein (ddRFP) pair [29]. cAMP binding to RAB-ICUE causes a conformational change that reduces ddRFP dimerization and thus decreases the fluorescence intensity. Single $\beta$-cells were transfected with RAB-ICUE using the 10- $\mu$ L neon transfection system kit (MPK1096, Invitrogen, Waltham, MA, USA). After $48 \mathrm{~h}$, the transfected $\beta$-cells were observed under a spinning disk confocal microscope (Olympus) equipped with a $40 \times 1.35$ numerical aperture (NA) oil objective lens. A 561-nm laser was used to excite RAB-ICUE fluorescence, and an Andor iXon3 897 EMCCD camera was used to collect emitted photons. The temperature of the extracellular solution (HBSS, 14025076, GIBCO, Grand Island, NE, USA) was maintained at $30-37^{\circ} \mathrm{C}$. 
Stimulation solutions (HBSS containing $100 \mathrm{nM}$ glucagon with $1 \mu \mathrm{M}$ MK0893 or $1 \mu \mathrm{M}$ Exendin 9-39) and inhibition solutions (HBSS containing $100 \mu \mathrm{M}$ NB001, $10 \mu \mathrm{M}$ NKY80, or $10 \mu \mathrm{M}$ KH7) were supplied to cells using a multichannel microperfusion system (MPS-2, Biogo, Wuhan, China). Because the fluorescence intensity of RAB-ICUE decreased when cAMP levels were elevated, we inverted the RAB-ICUE intensity curves to visualize the responses better. The key reagent information is as followed (Table 2).

Table 2. The information of adenylyl cyclase (AC) subtype inhibitors.

\begin{tabular}{ccc}
\hline Reagent & Source & Identifier \\
\hline NB001 & MedChemExpress & HY-14425 \\
NKY80 & Cayman & 17,777 \\
KH7 & Cayman & 13,243 \\
\hline
\end{tabular}

\subsection{RNA Extraction and Quantitative Real-Time PCR}

Total RNA was extracted from isolated islets using the RNeasy Mini Kit (74104, QiAGEN, Hilden, Germany). First-strand complementary DNA was synthesized from total RNA using the TransScript One-Step gDNA Removal and cDNA Synthesis SuperMix (AT311-03, TransGenBiotech, Beijing, China). Real-time PCR was performed on an Eppendorf RealPlex2 system using TransStart Top Green qPCR supermix (AQ13103, TransGenBiotech, Beijing, China). The qPCR primers used to detect Gcgr expression were Gcgr-F (5'-TTGCCACCTTCTCTGAGAGG-3') and Gcgr-R (5'-GTAAGGCCAGGAAGACAGGA-3'). The qPCR primers used to detect Glp1r expression were Glp1r-F (5'-CCTGTCGGAGTGTGAAGAGT-3') and Glp1r-R (5'-GCAAGTGTCTGAAGCCAACA $\left.-3^{\prime}\right)$. RNA transcript levels were quantified using the $2^{-\Delta \Delta C t}$ method by normalizing with GAPDH. Then, the results were normalized to the Gcgr ${ }^{\beta c e l l+/+}$ control.

\subsection{Pancreatic Sections and Immunohistochemistry}

Pancreases isolated from 16-week-old male mice were weighed, fixed in 4\% paraformaldehyde for $24 \mathrm{~h}$, and then embedded in paraffin. Then, $5 \mu \mathrm{m}$-thick sections were collected at $100-150 \mu \mathrm{m}$ intervals between two adjacent sections throughout the whole pancreas. Immunohistochemistry analysis was performed as previously described [30] using a mouse anti-insulin antibody (1:200, ZSGB-BIO, Beijing, China) and a rabbit anti-glucagon antibody simultaneously (1:200, ZSGB-BIO, Beijing, China). Finally, insulin-positive cells were colored red, while glucagon-positive cells were colored golden brown. Quantitative image analysis was performed using ImagePro Plus 6.0 software.

\subsection{Statistics}

All replicates are from, minimally, three separate experiments. All data were analyzed using SigmaPlot and GraphPad 7.0 software. The results are presented as the mean \pm SEM. Statistical significance was evaluated using Student's $t$-test for single Gaussian-distributed datasets or the Mann-Whitney rank-sum test for non-single Gaussian-distributed datasets. ${ }^{*} p<0.05,{ }^{* *} p<0.01,{ }^{* * *} p<0.001$.

\section{Results}

3.1. Glucagon Potentiates Insulin Secretion Via $\beta$-Cell GCGR at Physiological Concentrations of Glucose

To dissect the downstream receptor of glucagon, we measured insulin secretion from islets in the presence of either a GCGR antagonist (MK0893) or a GLP-1R antagonist (Exendin 9-39) (Table 1). At $20 \mathrm{mM}$ glucose, glucagon-stimulated insulin secretion was abolished by Exendin 9-39 but not MK0893 (Figure 1A), consistent with the dispensable role of GCGR previously reported $[18,19]$. However, reducing the incubating glucose concentration to $5 \mathrm{mM}$ made the glucagon effects susceptible to either GLP-1R or GCGR inhibition (Figure 1B). These results indicate that glucagon stimulates insulin secretion through GLP-1R at $20 \mathrm{mM}$ glucose, but through GLP-1R and GCGR at $5 \mathrm{mM}$ glucose. To 
exclude the possibility that the variable glucagon actions were due to the $\beta$-cells' heterogeneity within an islet, we used membrane capacitance recording to measure the size of the readily releasable pool (RRP) of exocytotic vesicles in individual mouse $\beta$-cells [31] (Figure S1). Under the perforated patch-clamp configuration, cytosolic contents with the cell were largely intact, which allowed for modulation of RRP by glucose and glucagon to be quantified. Again, glucagon-enhanced RRP from single $\beta$-cells in the presence of $20 \mathrm{mM}$ glucose was only sensitive to Exendin 9-39, while both MK0893 and Exendin 9-39 treatment eliminated the stimulatory effects of glucagon on RRP at $5 \mathrm{mM}$ glucose (Figure 1C,D). Taken together, the results with the supraphysiological dose of glucagon indicate glucagon stimulates insulin secretion through GLP-1R and GCGR at $5 \mathrm{mM}$ glucose, whereas $20 \mathrm{mM}$ glucose overrides the effects of GCGR.

A

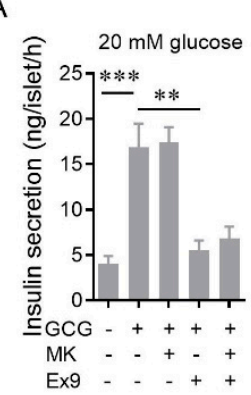

$E$

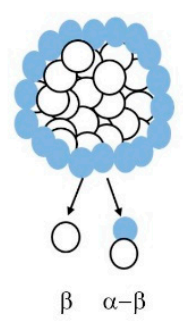

B
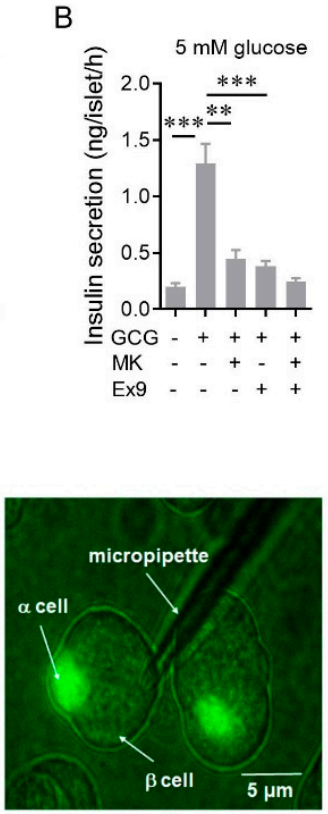

C

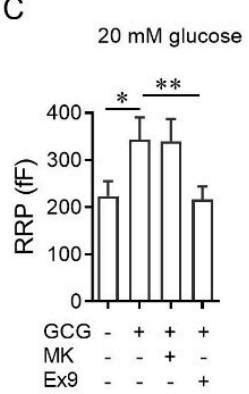

$\mathrm{F}$

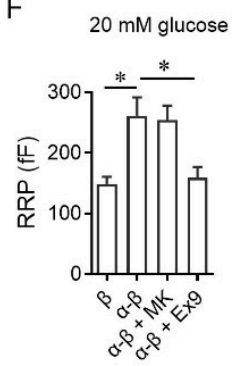

D

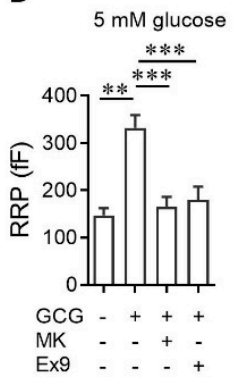

G

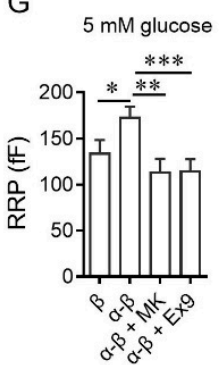

Figure 1. Glucagon potentiates insulin secretion via $\beta$-cell glucagon receptors (GCGR) at physiological doses of glucose. (A,B) Effects of MK0893 or Exendin 9-39 on $100 \mathrm{nM}$ glucagon-induced insulin secretion of isolated mouse islets in $20 \mathrm{mM}$ (A) and $5 \mathrm{mM}$ glucose (B) $(n=5-7$ per group). Glucagon is abbreviated as GCG, MK0893 is abbreviated as MK, and Exendin 9-39 is abbreviated as Ex9 in the figures. (C,D) Effects of MK0893 or Exendin 9-39 on $100 \mathrm{nM}$ glucagon-increased RRP size of single $\beta$-cells isolated from C57BL/6J mice in $20 \mathrm{mM}$ glucose (C) or $5 \mathrm{mM}$ glucose (D) $(n=16-25$ per condition). (E) Perforated patch on a $\alpha-\beta$ cell cluster. Left panel: schematic depicting the dissociation of GYY mouse islets into a $\alpha-\beta$ cell cluster or a single $\beta$-cell. Right panel: representative image of a perforated patch performing on a $\alpha-\beta$ cell cluster. $(\mathrm{F}, \mathrm{G})$ Effects of MK0893 and Exendin 9-39 on the RRP size of $\beta$-cells in $\alpha-\beta$ cell clusters isolated from GYY mice in $20 \mathrm{mM}$ glucose (F) or 5 mM glucose (G) ( $n=16-23$ per condition). Statistical significance was evaluated using Student's $t$-test for single Gaussian-distributed datasets or the Mann-Whitney rank-sum test for non-single Gaussian-distributed datasets. ${ }^{*} p<0.05,{ }^{* *} p<0.01,{ }^{* * *} p<0.001$.

We then tried to investigate whether endogenous glucagon released from $\alpha$-cells also modulates neighboring $\beta$-cell secretions through the same mechanisms. We used GluCre-ROSA26EYFP mice, in which $\alpha$-cells were labeled with eYFP [32] (Figure 1E), and compared the secretory abilities of single $\beta$-cells with those of $\alpha-\beta$ clusters. The mean size of the RRP in $\beta$-cells within $\alpha-\beta$ clusters was significantly larger than that in single $\beta$-cells, which was abolished by Exendin 9-39 but not by MK0893 at $20 \mathrm{mM}$ glucose (Figure 1F). This contrasts with the robust suppression of glucagon facilitated secretion by applying either MK0893 or Exendin 9-39 at $5 \mathrm{mM}$ glucose (Figure 1G). Overall, these data confirm that glucagon is a dual-receptor agonist that consistently activates GLP-1R to promote 
insulin secretion in the $5-20 \mathrm{mM}$ glucose range and enhances insulin secretion via $\beta$-cell GCGR at physiological glucose concentrations.

3.2. High Glucose Concentration Evokes cAMP Elevation via AC5 in $\beta$-Cells, Which Is Also Downstream of GCGR Activation, thus Bypassing GCGR in Promoting Insulin Secretion

The stimulatory effects of GCGR on $\beta$-cells diminished at $20 \mathrm{mM}$ glucose stimulation was unexpected and puzzling (Figure 1A,C,F). To explore the possible mechanism, we transfected primary mouse $\beta$-cells with RAB-ICUE [28], a genetically encoded cAMP fluorescence indicator. Additional glucagon stimulated a pronounced elevation of cAMP signal that was almost abolished when MK0893 and Exendin 9-39 were used together at $5 \mathrm{mM}$ glucose (Figure 2A,B). Application of either antagonist significantly reduced but did not block the glucagon-evoked cAMP signal elevation, demonstrating additive effects of GCGR and GLP-1R at $5 \mathrm{mM}$ glucose (Figure 2A,B). On the other hand, $\beta$-cells stimulated with 7,11 , or $20 \mathrm{mM}$ glucose alone exhibited elevated cytosolic cAMP signals, which were further potentiated by the application of glucagon (Figure 2C-E). Both GCGR and GLP-1R activation contributed to glucagon-stimulated cAMP elevation at $7 \mathrm{mM}$ glucose, similar to that detected at $5 \mathrm{mM}$ glucose (Figure 2C). However, at 11 and $20 \mathrm{mM}$ glucose, GCGR inhibition failed to reduce high glucagon-stimulated cAMP elevation, which was eliminated by suppressing GLP-1R function (Figure 2D,E). We hypothesize that the reason that GCGR activation further increases cAMP at physiological but not at high glucose concentrations is that GCGR and high glucose may recruit the same AC subtype to transform ATP into cAMP. We used NB001, NKY80, and KH7 to inhibit AC1, AC5, and AC10, respectively (Table 2). NKY80 inhibited high glucose- or GCGR- but not GLP-1R-stimulated cAMP elevation (Figure 2F), indicating that AC5 is the common downstream target of GCGR activation and high glucose stimulation. Our results suggest that under high glucose stimulation, a high level of ATP occupied all AC5 to synthesize cAMP, and GCGR could not recruit more AC5 and thus could not further increase cAMP level.

\subsection{The Physiological Function of $\beta$-Cell GCGR Becomes Upregulated and More Essential to Glucose Homeostasis in Mice Fed HFD}

As high glucose bypassed the action of $\beta$-cells' GCGR on cAMP elevation in vitro, we further examine whether $\beta$-cells' GCGR physiologically modulate glucose homeostasis in vivo. We created $\beta$-cell-specific GCGR knockout mice (Gcgr ${ }^{\beta c e l l-/-}$, genotype: Ins1-cre; Gcgrfff) (Figure 3A,B), in which $\beta$-cell mass and islet architecture were similar to those of control mice (Figure S2A-E).

Similar to the pharmacological experiments (Figures 1 and 2B-E), isolated islets from $\beta$-cell-specific GCGR knockout mice showed compromised insulin secretion under 5- or 7-mM glucose stimulation, but similar GSIS to the control islets under 11 or $20 \mathrm{mM}$ glucose (Figure 3C). Interestingly, although displayed normal glucose tolerance at regular doses of glucose intraperitoneal injection $(4 \mathrm{~g} / \mathrm{kg}, 2 \mathrm{~g} / \mathrm{kg}$, Figure 3D,E,G), Gcgr Bcell-/- mice became glucose-intolerant after injection of a small dose of glucose $(1 \mathrm{~g} / \mathrm{kg}$, Figure $3 \mathrm{~F}, \mathrm{G})$. Consistent with the data of isolated islets and $\beta$-cells, this result reinforced the conclusion that endogenously released glucagon enhances $\beta$-cell secretion and regulates blood glucose via the GCGR pathway at physiological glucose levels. 
A

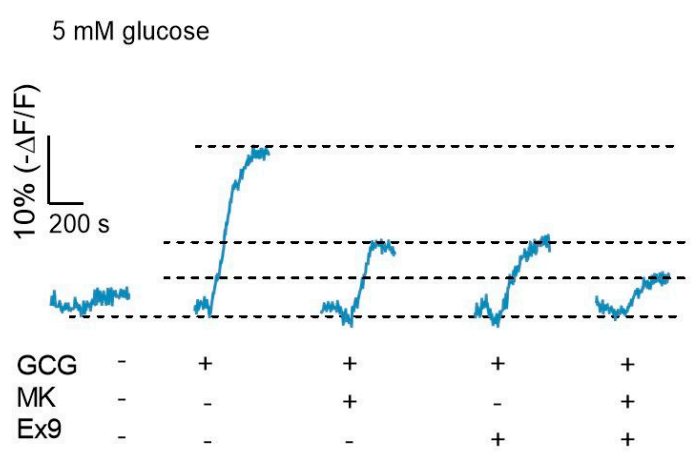

C

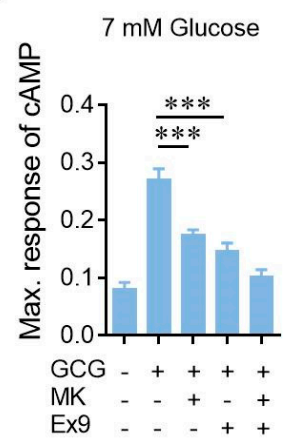

B

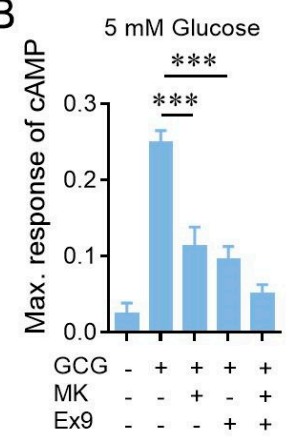

E

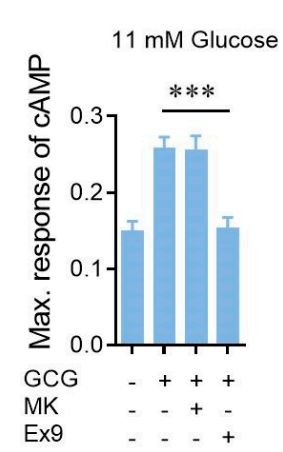

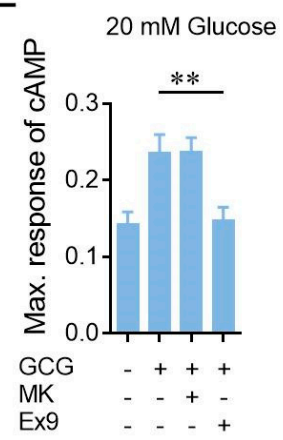

F

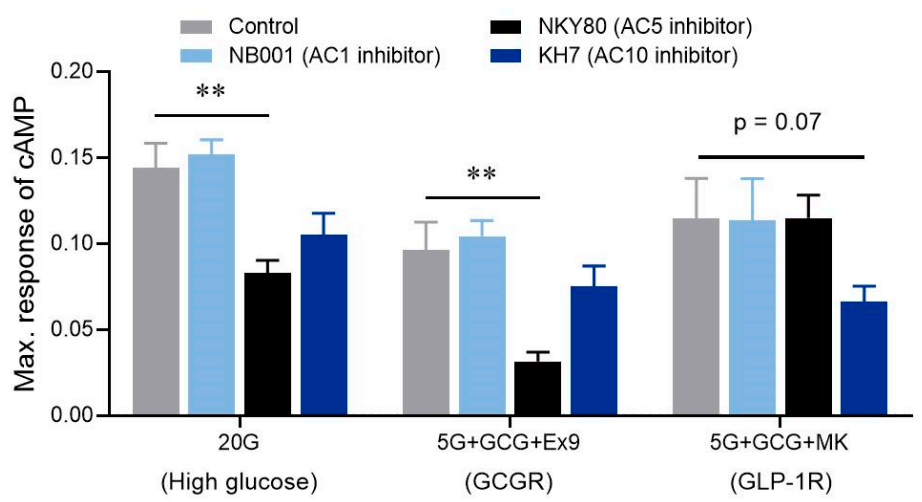

Figure 2. High glucose activates the same ACs as GCGR activation to increase the cAMP signal. (A) Average curves of intracellular cAMP signaling in $\beta$-cells induced by $100 \mathrm{nM}$ glucagon and effects of MK0893 or Exendin 9-39 on glucagon-induced cAMP signaling in $5 \mathrm{mM}$ glucose $(n=17-21$ per condition). (B) Maximum responses of intracellular cAMP signaling calculated from (A). (C-E) Maximum responses of intracellular cAMP signaling in $\beta$-cells induced by $100 \mathrm{nM}$ glucagon and effects of MK0893 or Exendin 9-39 on glucagon-induced cAMP signaling in $7 \mathrm{mM}$ glucose (C), $11 \mathrm{mM}$ glucose (D), $20 \mathrm{mM}$ glucose (E) ( $n=15-19$ per condition). (F) Effects of different adenylate cyclase (AC) inhibitors on high glucose-, GCGR- and GLP-1R-stimulated cAMP elevations ( $n=17-19$ per condition). $100 \mu \mathrm{M}$ NB001, $10 \mu \mathrm{M}$ NKY80, and $10 \mu \mathrm{M}$ KH7 inhibit AC1, AC5, and AC10, respectively. Statistical significance was evaluated using Student's $t$-test for single Gaussian-distributed datasets or the Mann-Whitney rank-sum test for non-single Gaussian-distributed datasets. ${ }^{* *} p<0.01$, *** $p<0.001$. 
A
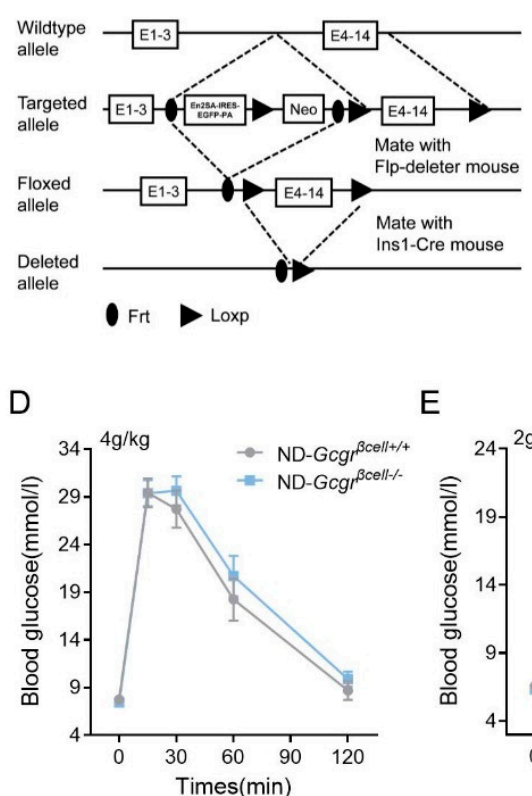

G

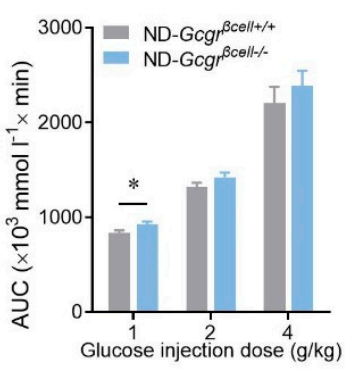

$\mathrm{J}$

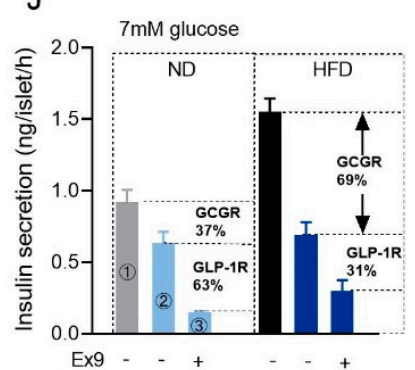

B

E

$$
\mathrm{H}
$$

K
B

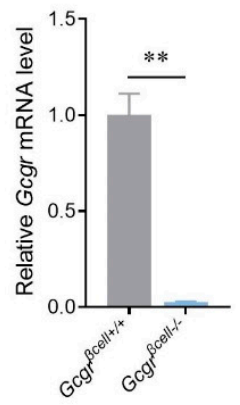

C

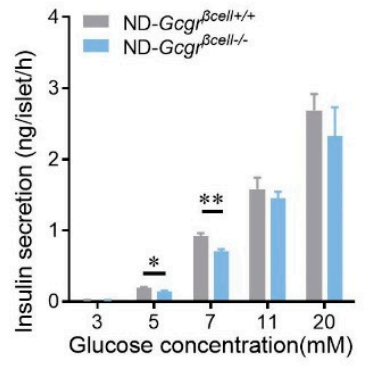

F

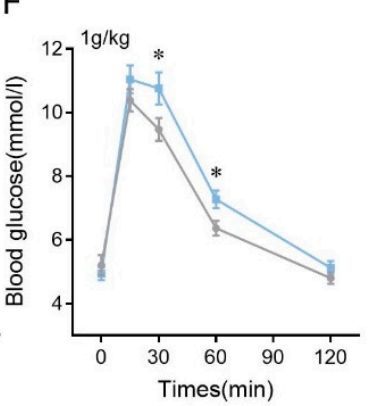

I
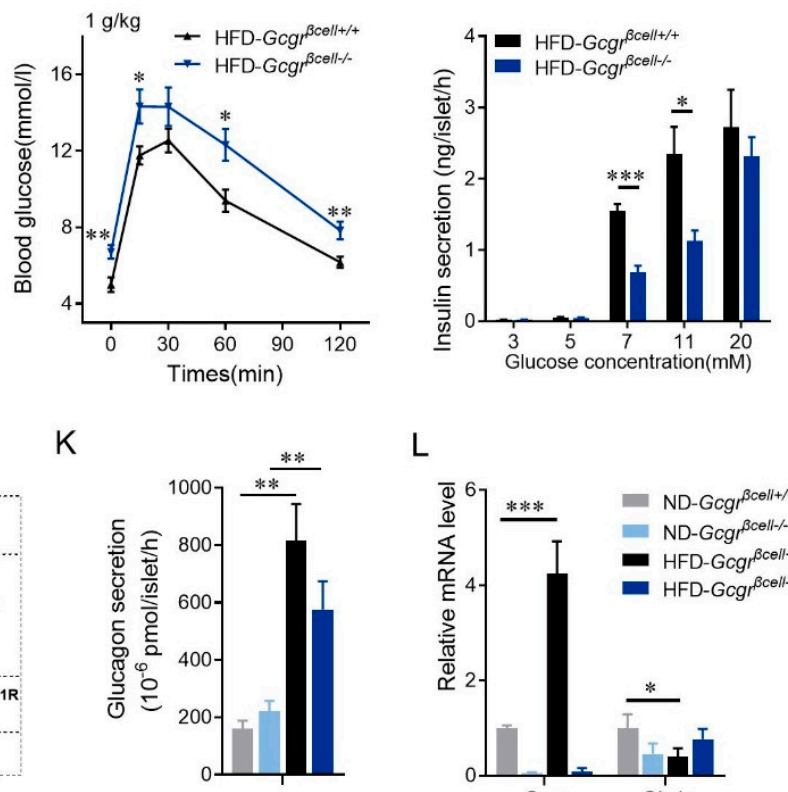

L

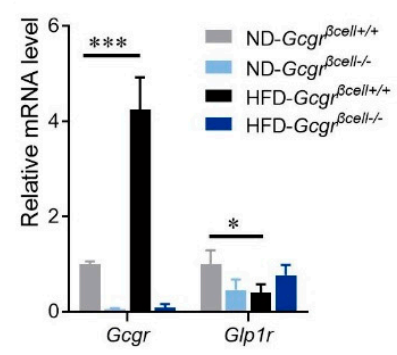

Figure 3. The physiological function of $\beta$-cell GCGR becomes upregulated and essential to glucose homeostasis in mice fed high-fat diets (HFD). (A) Schematic depicting the strategy for generating $\beta$-cell GCGR knockout mice. (B) Knockout efficiency of Gcgr mRNA in Gcgr Bcell-/- mouse islets. (C) Insulin secretion of isolated islets from Gcgr ${ }^{\beta c e l l+/+}$ and $\mathrm{Gcgr}^{\beta c e l l-/-}$ mice fed the normal diet (ND) at different glucose concentrations $(3 \mathrm{mM}, 5 \mathrm{mM}, 7 \mathrm{mM}, 11 \mathrm{mM}$ and $20 \mathrm{mM})(n=5-9$ per condition). (D-F) Intraperitoneal glucose tolerance tests (IPGTTs) on Gcgr ${ }^{\beta c e l l+/+}$ and Gcgr ${ }^{\beta c e l l-/-}$ mice fed the ND injected with different doses of glucose. The glucose doses were $4 \mathrm{~g} / \mathrm{kg}$ (D), $2 \mathrm{~g} / \mathrm{kg}$ (E), and $1 \mathrm{~g} / \mathrm{kg}$ (F) ( $n=12-14$ mice per condition). (G) The areas under the curves (AUCs) of the intraperitoneal glucose tolerance tests (IPGTTs) on Gcgr ${ }^{\beta c e l l+/+}$ and Gcgr ${ }^{\beta c e l l-/-}$ mice fed the ND injected with different doses of glucose $(1 \mathrm{~g} / \mathrm{kg}, 2 \mathrm{~g} / \mathrm{kg}$, and $4 \mathrm{~g} / \mathrm{kg})(n=12-14$ mice per condition). (H) IPGTTs on Gcgr $\gamma^{\beta c e l l+/+}$ and Gcgr ${ }^{\beta c e l l-/-}$ mice fed the HFD injected with $1 \mathrm{~g} / \mathrm{kg}$ glucose $(n=12-15$

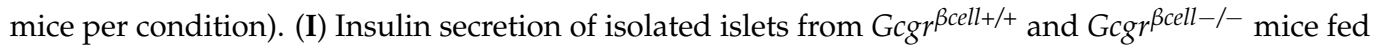


the HFD at different glucose concentrations ( $3 \mathrm{mM}, 5 \mathrm{mM}, 7 \mathrm{mM}, 11 \mathrm{mM}$ and $20 \mathrm{mM})(n=5-9$ per condition). (J) Contributions of GCGR and GLP-1R on insulin secretion of isolated islets from Gcgr $\beta$ cell+/+ and Gcgr $\beta$ cell-/- mice fed the ND or HFD in $7 \mathrm{mM}$ glucose ( $n=6-7$ per condition). The proportions of GCGR and GLP-1R contributions are calculated as follows. The enhanced insulin secretion by glucagon is via activation of both GCGR and GLP-1R. Therefore, in mice fed the ND, the total amount of enhanced insulin secretion by glucagon equals the difference of insulin secretion between Gcgr $\beta c e l l+/+$ islets and Gcgr $\beta c e l l-/-$ islets pretreated with Exendin 9-39 (1)-(3)). In this regard, the contribution of GCGR and GLP-1R were 37\% ((1)-(2))/(1)-(3))) and 63\% ((2)-(3)/(1)-(3))), respectively. The same method was applied on mice fed the HFD. (K) Glucagon secretion from isolated islets of Gcgr Bcell+/+ and Gcgr $\beta$ cell-/- mice fed the ND or HFD under stimulation with $7 \mathrm{mM}$ glucose ( $n=4$ per condition). (L) Relative mRNA levels of Gcgr, Glp1r in islets from Gcgr ${ }^{\beta c e l l+/+}$ and Gcgr $\beta$ cell-/- mice fed the ND or HFD ( $n=3-4$ per condition). Statistical significance was evaluated using Student's $t$-test for single Gaussian-distributed datasets or the Mann-Whitney rank-sum test for non-single Gaussian-distributed datasets. ${ }^{*} p<0.05,{ }^{* *} p<0.01,{ }^{* * *} p<0.001$.

In contrast to the subtle phenotype under the ND, Gcgr ${ }^{\beta c e l l-/-}$ mice fed HFD had more severe hyperglycemia and glucose intolerance (Figure $3 \mathrm{H}$ and Figure S3A-C). Along with this phenotype, insulin secretion evoked by $7 \mathrm{mM}$ and $11 \mathrm{mM}$ glucose was reduced by half in the islets of Gcgr ${ }^{\beta c e l l-/-}$ mice fed HFD compared to the control mice fed HFD (Figure 3I), and the differences were much higher than those between $G c g r \beta c e l l-/-$ and control mice fed ND (Figure 3C,I). By comparing the insulin secretion evoked by $7 \mathrm{mM}$ glucose or $7 \mathrm{mM}$ glucose combined with Exendin 9-39 from Gcgr ${ }^{\beta c e l l+/+}$ and Gcgr ${ }^{\beta c e l l-/-}$ islets, we concluded that GCGR and GLP-1R contributed 37\% and 63\% of the stimulatory effects of glucagon in mice fed ND, respectively. In mice fed HFD, these numbers changed to $69 \%$ and $31 \%$, respectively (Figure 3J), highlighting the critical up-regulation of $\beta$-cell GCGR function in maintaining glucose tolerance under HFD. In line with these data, compared to the controls fed ND, we also observed a 3-4-fold increase in glucagon released from islets isolated from HFD mice (Figure 3K), significant upregulation of Gcgr mRNA, and downregulation of Glp-1r mRNA in islets (Figure 3L).

Overall, and differently from previous studies [18-20,33], we have shown a powerful effect of glucagon-activated GCGR in potentiating insulin secretion at physiological glucose concentrations, possibly via the AC5 not used by the GLP-1R. Moreover, we demonstrate that the essential role of $\beta$-cells' GCGR in regulating physiological glucose homeostasis becomes more critical during nutrient overload.

\section{Discussion}

The physiological function of GCGR on $\beta$-cells has not been elucidated, albeit glucagon stimulates insulin secretion. The effect of glucagon or $\alpha$-cells on $\beta$-cell insulin secretion is thought to depend on GLP-1R. Here, our results highlight the vital role of GCGR on $\beta$-cells in regulating insulin secretion at the physiological condition and during metabolic stress.

Although whole-body GCGR knockout (Gcgr-/-) mice exhibited reduced GSIS [34], the phenotype was primarily due to alterations in islet structures induced by the absence of the liver GCGR $[35,36]$. GCGR on $\beta$-cells was believed dispensable for insulin secretion [18-20]. Our results here indicate that this dogma is only partially true. We suggest that the effect of GCGR activation on cAMP elevation is only dispensable at high glucose, but necessary at physiologically relevant doses of glucose. Most of the previous studies focused on insulin secretion stimulated by high glucose but neglected the effect of GCGR on insulin secretion stimulated by the physiological dose of glucose. The latter is difficult to be identified as, even in our study, Gcgr ${ }^{\beta c e l l-/-}$ mice did not show glucose intolerance when, being IP, injected with $2 \mathrm{~g} / \mathrm{kg}$ and $4 \mathrm{~g} / \mathrm{kg}$ glucose. The phenotype of glucose intolerance was only identified when injected with $1 \mathrm{~g} / \mathrm{kg}$ glucose. We conducted some preliminary exploration of the underlying mechanisms, finding that $20 \mathrm{mM}$ glucose and GCGR mobilized the same pool of ACs, AC5 (Figure 2F). High glucose metabolism produces a lot of ATP, thus the limiting factor is the number of recruited ACs that convert ATP into cAMP [37,38]. 
When high glucose activates all available AC5, GCGR does not further increase active AC5 to promote CAMP levels, and thus becomes dispensable at high glucose-stimulated insulin secretion. GLP-1R probably activates other ACs, such as AC10, further raising cAMP levels and thus enhancing high glucose-stimulated insulin secretion. At lower glucose conditions, due to the low ATP level, the number of active ACs and ATP level are the limiting factors of cAMP level. GCGR activation helps to recruit more AC5, thereby increasing cAMP levels and insulin secretion. Further studies are needed to confirm this hypothesis.

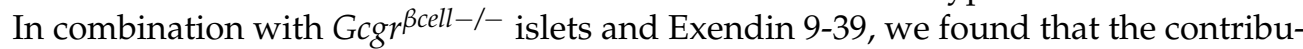
tion ratio of GCGR and GLP-1R to glucagon-enhanced $7 \mathrm{mM}$ glucose-stimulated insulin secretion was 37:63 in ND-fed mice (Figure 3J). Interestingly, the ratio was reversed to 69:31 in mice fed HFD (Figure 3J). This means that GCGR becomes more critical in amplifying GSIS under metabolic stress. This was consistent with the enhanced glucagon secretion, increased Gcgr gene expression and reduced Glp1r expression in the islets of mice fed HFD (Figure 3K,L). The underlying mechanisms need more studies to unravel.

Glucagon acts as the natural dual-receptor agonist of both GLP-1R and GCGR. Designing drugs with the optimal combination of GLP-1R and GCGR activation is important and may confer greater benefits in reversing diabetes than GLP-1R activation alone, as demonstrated recently [39-42]. However, the more potent activation of GCGR by excessive glucagon may upset this intricate balance and lead to overall adverse and diabetogenic effects, such as inducing more glucose production in the liver, which participates in and contributes to the progression of T2D, as confirmed [43]. Our study demonstrates that the contribution of GCGR to insulin secretion is significantly increased relative to GLP-1R in HFD-fed mice. As human islets have more intermixed $\alpha-\beta$ cell interfaces [44-46], the proportion of GCGR:GLP-1R effect may be more critical for human islet function to keep a narrower normal glycemic fluctuation. Therefore, we suggest that the changes in the effects of GCGR and GLP-1R induced by metabolic stress should also be considered when designing GCGR- and GLP-1R-combined agonists for the treatment of diabetes.

Supplementary Materials: The following are available online at https://www.mdpi.com/article/10 .3390 / cells10092495/s1, Figure S1. Exocytosis signals of a representative $\beta$-cell induced by a stimulus protocol of pulses depolarized $(-70 \mathrm{mV}$ to $0 \mathrm{mV})$ via a voltage clamp in the perforated whole-cell configuration, Figure S2. The islet structure, number, and size in Gcgr ${ }^{\beta c e l l-/-}$ mice, Figure S3. The AUCs, FPG and 2h-PG of Gcgr Bcell-/- mice fed the ND or HFD.

Author Contributions: Y.L. and L.C. conceived and supervised the research; Y.Z. and C.H. equally participated in designing and performing experiments, data analysis, and figure preparation. W.Z. participated in the initial phase of the project and some of the data collection. G.Y. and X.P. participated in some of the data collection. S.M. and J.Z. developed the RAB-ICUE indicator and helped with the single-cell cAMP measurement experiments. Y.L. and L.C. wrote the paper. All authors participated in discussions and data interpretation. All authors have read and agreed to the published version of the manuscript.

Funding: This research was funded by grants from the National Science and Technology Major Project Program (2016YFA0500400), the National Natural Science Foundation of China (91854112, 31327901, 31521062, 31570839, 32070819 and 91750203), Beijing Natural Science Foundation (L172003), and the National Key R\&D Program of China (2019YFE0106700). X.P. is supported by Postdoc fellowship of Peking- Tsinghua Center for Life Sciences.

Institutional Review Board Statement: The study was conducted according to the guidelines of the Declaration of Helsinki and approved by the Ethics Committee of Peking University (protocol code \#IMM-ChenLY-1, August 2013).

Informed Consent Statement: Not applicable.

Data Availability Statement: The data presented in this study are available on request from the corresponding author.

Conflicts of Interest: The authors declare no conflict of interest. 


\section{References}

1. Unger, R.H.; Aguilar-Parada, E.; Müller, W.A.; Eisentraut, A.M. Studies of pancreatic alpha cell function in normal and diabetic subjects. J. Clin. Investig. 1970, 49, 837-848. [CrossRef] [PubMed]

2. Perley, M.J.; Kipnis, D.M. Plasma insulin responses to oral and intravenous glucose: Studies in normal and diabetic subjects. J. Clin. Investig. 1967, 46, 1954. [CrossRef] [PubMed]

3. Dupre, J.; Ross, S.; Watson, D.; Brown, J. Stimulation of insulin secretion by gastric inhibitory polypeptide in man. J. Clin. Endocrinol. Metab. 1973, 37, 826-828. [CrossRef]

4. Schmidt, W.; Siegel, E.; Creutzfeldt, W. Glucagon-like peptide-1 but not glucagon-like peptide-2 stimulates insulin release from isolated rat pancreatic islets. Diabetologia 1985, 28, 704-707. [CrossRef]

5. Kreymann, B.; Williams, G.; Ghatei, M.A.; Bloom, S.R. Glucagon-like peptide-1 7-36: A physiological incretin in man. Lancet 1987, 2, 1300-1304. [CrossRef]

6. Nauck, M.A.; Heimesaat, M.M.; Orskov, C.; Holst, J.J.; Ebert, R.; Creutzfeldt, W. Preserved Incretin Activity of Glucagon-Like Peptide-1 [7-36 Amide] but Not of Synthetic Human Gastric-Inhibitory Polypeptide in Patients with Type-2 Diabetes-Mellitus. J. Clin. Investig. 1993, 91, 301-307. [CrossRef]

7. Smith, E.P.; An, Z.; Wagner, C.; Lewis, A.G.; Cohen, E.B.; Li, B.; Mahbod, P.; Sandoval, D.; Perez-Tilve, D.; Tamarina, N.; et al. The role of beta cell glucagon-like peptide-1 signaling in glucose regulation and response to diabetes drugs. Cell Metab. 2014, 19, 1050-1057. [CrossRef]

8. Wideman, R.D.; Irene, L.; Webber, T.D.; Verchere, C.B.; Johnson, J.D.; Cheung, A.T.; Kieffer, T.J. Improving function and survival of pancreatic islets by endogenous production of glucagon-like peptide 1 (GLP-1). Proc. Natl. Acad. Sci. USA 2006, 103, 13468-13473. [CrossRef]

9. Donath, M.Y.; Burcelin, R. GLP-1 effects on islets: Hormonal, neuronal, or paracrine? Diabetes Care 2013, 36, S145-S148. [CrossRef]

10. Whalley, N.M.; Pritchard, L.E.; Smith, D.M.; White, A. Processing of proglucagon to GLP-1 in pancreatic alpha-cells: Is this a paracrine mechanism enabling GLP-1 to act on beta-cells? J. Endocrinol. 2011, 211, 99-106. [CrossRef]

11. Masur, K.; Tibaduiza, E.C.; Chen, C.; Ligon, B.; Beinborn, M. Basal receptor activation by locally produced glucagon-like peptide-1 contributes to maintaining beta-cell function. Mol. Endocrinol. 2005, 19, 1373-1382. [CrossRef]

12. Kilimnik, G.; Kim, A.; Steiner, D.F.; Friedman, T.C.; Hara, M. Intraislet production of GLP-1 by activation of prohormone convertase 1/3 in pancreatic alpha-cells in mouse models of ss-cell regeneration. Islets 2010, 2, 149-155. [CrossRef] [PubMed]

13. Chambers, A.P.; Sorrell, J.E.; Haller, A.; Roelofs, K.; Hutch, C.R.; Kim, K.S.; Gutierrez-Aguilar, R.; Li, B.; Drucker, D.J.; D’Alessio, D.A.; et al. The Role of Pancreatic Preproglucagon in Glucose Homeostasis in Mice. Cell Metab. 2017, 25, 927-934.e923. [CrossRef] [PubMed]

14. Traub, S.; Meier, D.T.; Schulze, F.; Dror, E.; Nordmann, T.M.; Goetz, N.; Koch, N.; Dalmas, E.; Stawiski, M.; Makshana, V.; et al. Pancreatic alpha Cell-Derived Glucagon-Related Peptides Are Required for beta Cell Adaptation and Glucose Homeostasis. Cell Rep. 2017, 18, 3192-3203. [CrossRef] [PubMed]

15. Marchetti, P.; Lupi, R.; Bugliani, M.; Kirkpatrick, C.L.; Sebastiani, G.; Grieco, F.A.; Del Guerra, S.; D'Aleo, V.; Piro, S.; Marselli, L.; et al. A local glucagon-like peptide 1 (GLP-1) system in human pancreatic islets. Diabetologia 2012, 55, 3262-3272. [CrossRef]

16. Samols, E.; Marri, G.; Marks, V. Promotion of insulin secretion by glucagon. Lancet 1965, 286, 415-416. [CrossRef]

17. Moens, K.; Flamez, D.; Van Schravendijk, C.; Ling, Z.; Pipeleers, D.; Schuit, F. Dual glucagon recognition by pancreatic beta-cells via glucagon and glucagon-like peptide 1 receptors. Diabetes 1998, 47, 66-72. [CrossRef]

18. Svendsen, B.; Larsen, O.; Gabe, M.B.N.; Christiansen, C.B.; Rosenkilde, M.M.; Drucker, D.J.; Holst, J.J. Insulin Secretion Depends on Intra-islet Glucagon Signaling. Cell Rep. 2018, 25, 1127-1134.e1122. [CrossRef]

19. Capozzi, M.E.; Svendsen, B.; Encisco, S.E.; Lewandowski, S.L.; Martin, M.D.; Lin, H.; Jaffe, J.L.; Coch, R.W.; Haldeman, J.M.; MacDonald, P.E.; et al. beta Cell tone is defined by proglucagon peptides through cAMP signaling. JCI Insight 2019, 4, e126742. [CrossRef]

20. Capozzi, M.E.; Wait, J.B.; Koech, J.; Gordon, A.N.; Coch, R.W.; Svendsen, B.; Finan, B.; D'Alessio, D.A.; Campbell, J.E. Glucagon lowers glycemia when beta-cells are active. JCI Insight 2019, 5, e129954. [CrossRef]

21. Thorens, B.; Tarussio, D.; Maestro, M.A.; Rovira, M.; Heikkila, E.; Ferrer, J. Ins1(Cre) knock-in mice for beta cell-specific gene recombination. Diabetologia 2015, 58, 558-565. [CrossRef] [PubMed]

22. Liang, K.; Du, W.; Lu, J.; Li, F.; Yang, L.; Xue, Y.; Hille, B.; Chen, L. Alterations of the Ca ${ }^{2+}$ signaling pathway in pancreatic beta-cells isolated from $\mathrm{db} / \mathrm{db}$ mice. Protein Cell 2014, 5, 783-794. [CrossRef]

23. Xiong, Y.; Guo, J.; Candelore, M.R.; Liang, R.; Miller, C.; Dallas-Yang, Q.; Jiang, G.; McCann, P.E.; Qureshi, S.A.; Tong, X. Discovery of a Novel Glucagon Receptor Antagonist N-[(4-\{(1 S)-1-[3-(3, 5-Dichlorophenyl)-5-(6-methoxynaphthalen-2-yl)-1 H-pyrazol-1-yl] ethyl\} phenyl) carbonyl]- $\beta$-alanine (MK-0893) for the Treatment of Type II Diabetes. J. Med. Chem. 2012, 55, 6137-6148. [CrossRef] [PubMed]

24. Anderberg, R.H.; Richard, J.E.; Eerola, K.; Ferreras, L.L.; Nordbeck, E.B.; Hansson, C.; Nissbrandt, H.; Berqquist, F.; Gribble, F.M.; Reimann, F. Glucagon-like peptide- 1 and its analogues act in the dorsal raphe and modulate central serotonin to reduce appetite and body weight. Diabetes 2017, 66, 1062-1073. [CrossRef] [PubMed]

25. De Marinis, Y.Z.; Salehi, A.; Ward, C.E.; Zhang, Q.; Abdulkader, F.; Bengtsson, M.; Braha, O.; Braun, M.; Ramracheya, R.; Amisten, S. GLP-1 inhibits and adrenaline stimulates glucagon release by differential modulation of $\mathrm{N}$-and L-type Ca ${ }^{2+}$ channel-dependent exocytosis. Cell Metab. 2010, 11, 543-553. [CrossRef] 
26. Zhou, Z.; Misler, S. Amperometric detection of quantal secretion from patch-clamped rat pancreatic beta-cells. J. Biol. Chem. 1996, 271, 270-277. [CrossRef]

27. Dou, H.Q.; Xu, Y.F.; Sun, J.P.; Shang, S.; Guo, S.; Zheng, L.H.; Chen, C.C.; Bruce, I.C.; Yu, X.; Zhou, Z. Thiopental-induced insulin secretion via activation of IP3-sensitive calcium stores in rat pancreatic beta-cells. Am. J. Physiol. Cell Physiol. 2012, 302, C796-C803. [CrossRef]

28. Mehta, S.; Zhang, Y.; Roth, R.H.; Zhang, J.F.; Mo, A.; Tenner, B.; Huganir, R.L.; Zhang, J. Single-fluorophore biosensors for sensitive and multiplexed detection of signalling activities. Nat Cell Biol 2018, 20, 1215-1225. [CrossRef] [PubMed]

29. Alford, S.C.; Abdelfattah, A.S.; Ding, Y.; Campbell, R.E. A fluorogenic red fluorescent protein heterodimer. Chem. Biol. 2012, 19, 353-360. [CrossRef]

30. Wang, Y.; Han, C.; Zhu, W.; Wu, Z.; Liu, Y.; Chen, L. An optical method to evaluate both mass and functional competence of pancreatic $\alpha$-and $\beta$-cells. J. Cell Sci. 2016, 129, 2462-2471. [CrossRef]

31. Rorsman, P.; Renstrom, E. Insulin granule dynamics in pancreatic beta cells. Diabetologia 2003, 46, 1029-1045. [CrossRef]

32. Quoix, N.; Cheng-Xue, R.; Guiot, Y.; Herrera, P.L.; Henquin, J.C.; Gilon, P. The GluCre-ROSA26EYFP mouse: A new model for easy identification of living pancreatic alpha-cells. FEBS Lett. 2007, 581, 4235-4240. [CrossRef]

33. Moens, K.; Berger, V.; Ahn, J.M.; Van Schravendijk, C.; Hruby, V.J.; Pipeleers, D.; Schuit, F. Assessment of the role of interstitial glucagon in the acute glucose secretory responsiveness of in situ pancreatic beta-cells. Diabetes 2002, 51, 669-675. [CrossRef]

34. Sorensen, H.; Winzell, M.S.; Brand, C.L.; Fosgerau, K.; Gelling, R.W.; Nishimura, E.; Ahren, B. Glucagon receptor knockout mice display increased insulin sensitivity and impaired beta-cell function. Diabetes 2006, 55, 3463-3469. [CrossRef]

35. Vuguin, P.M.; Kedees, M.H.; Cui, L.; Guz, Y.; Gelling, R.W.; Nejathaim, M.; Charron, M.J.; Teitelman, G. Ablation of the glucagon receptor gene increases fetal lethality and produces alterations in islet development and maturation. Endocrinology 2006, 147, 3995-4006. [CrossRef]

36. Longuet, C.; Robledo, A.M.; Dean, E.D.; Dai, C.H.; Ali, S.; McGuinness, I.; de Chavez, V.; Vuguin, P.M.; Charron, M.J.; Powers, A.C.; et al. Liver-Specific Disruption of the Murine Glucagon Receptor Produces alpha-Cell Hyperplasia Evidence for a Circulating alpha-Cell Growth Factor. Diabetes 2013, 62, 1196-1205. [CrossRef]

37. Hodson, D.J.; Mitchell, R.K.; Marselli, L.; Pullen, T.J.; Brias, S.G.; Semplici, F.; Everett, K.L.; Cooper, D.M.; Bugliani, M.; Marchetti, P. ADCY5 couples glucose to insulin secretion in human islets. Diabetes 2014, 63, 3009-3021. [CrossRef] [PubMed]

38. Leech, C.A.; Castonguay, M.A.; Habener, J.F. Expression of adenylyl cyclase subtypes in pancreatic $\beta$-cells. Biochem. Biophys. Res. Commun. 1999, 254, 703-706. [CrossRef] [PubMed]

39. Day, J.W.; Ottaway, N.; Patterson, J.T.; Gelfanov, V.; Smiley, D.; Gidda, J.; Findeisen, H.; Bruemmer, D.; Drucker, D.J.; Chaudhary, N.; et al. A new glucagon and GLP-1 co-agonist eliminates obesity in rodents-SI. Nat. Chem. Biol. 2009, 5, 749-757. [CrossRef]

40. Sadry, S.A.; Drucker, D.J. Emerging combinatorial hormone therapies for the treatment of obesity and T2DM. Nat. Rev. Endocrinol. 2013, 9, 425-433. [CrossRef] [PubMed]

41. Parker, J.A.; McCullough, K.A.; Field, B.C.; Minnion, J.S.; Martin, N.M.; Ghatei, M.A.; Bloom, S.R. Glucagon and GLP-1 inhibit food intake and increase c-fos expression in similar appetite regulating centres in the brainstem and amygdala. Int. J. Obes. 2013, 37, 1391-1398. [CrossRef]

42. Pocai, A.; Carrington, P.E.; Adams, J.R.; Wright, M.; Eiermann, G.; Zhu, L.; Du, X.; Petrov, A.; Lassman, M.E.; Jiang, G.; et al. Glucagon-like peptide 1/glucagon receptor dual agonism reverses obesity in mice. Diabetes 2009, 58, 2258-2266. [CrossRef] [PubMed]

43. Unger, R.H.; Cherrington, A.D. Glucagonocentric restructuring of diabetes: A pathophysiologic and therapeutic makeover. J. Clin. Investig. 2012, 122, 4-12. [CrossRef] [PubMed]

44. Brissova, M.; Fowler, M.J.; Nicholson, W.E.; Chu, A.; Hirshberg, B.; Harlan, D.M.; Powers, A.C. Assessment of human pancreatic islet architecture and composition by laser scanning confocal microscopy. J. Histochem. Cytochem. 2005, 53, 1087-1097. [CrossRef] [PubMed]

45. Cabrera, O.; Berman, D.M.; Kenyon, N.S.; Ricordi, C.; Berggren, P.O.; Caicedo, A. The unique cytoarchitecture of human pancreatic islets has implications for islet cell function. Proc. Natl. Acad. Sci. USA 2006, 103, 2334-2339. [CrossRef]

46. Rodriguez-Diaz, R.; Molano, R.D.; Weitz, J.R.; Abdulreda, M.H.; Berman, D.M.; Leibiger, B.; Leibiger, I.B.; Kenyon, N.S.; Ricordi, C.; Pileggi, A.; et al. Paracrine Interactions within the Pancreatic Islet Determine the Glycemic Set Point. Cell Metab. 2018, 27, 549-558.e544. [CrossRef] 